\title{
Immigrant Capital and Entrepreneurial Opportunities
}

\author{
Malavika Sundararajan, Binod Sundararajan
}

\begin{abstract}
A B S T R A C T
Objective: The main objective of this study is to define and operationalize the concept of immigrant capital, a key factor that differentiates immigrant from host country entrepreneurs in how they recognize and start new ventures.

Research Design \& Methods: Using grounded theory, we synthesized the outcomes from the analysis of eight Canadian and U.S. case studies of successful immigrant entrepreneurs with the key findings from the literature to define and develop a model of immigrant capital.
\end{abstract}

Findings: Based on our grounded theory development process we show that the concept of immigrant capital as a distillate of human, cultural, economic and social capital that goes beyond expected opportunity recognition (OR) drivers like prior knowledge and prior experience to differentiate and enhance the immigrant entrepreneur's ability to recognize business opportunities compared to host country entrepreneurs.

Implications \& Recommendations: Understanding a unique resource like immigrant capital, will help immigrant as well as host country entrepreneurs further develop their opportunity recognition ability by bridging gaps and fulfilling the needs for both, immigrant and host country consumers.

Contribution \& Value Added: The main contribution is the theoretical development, identification and definition of the immigrant capital model and propositions that will articulate the factors that lead to the conceptualization and operationalization of immigrant capital.

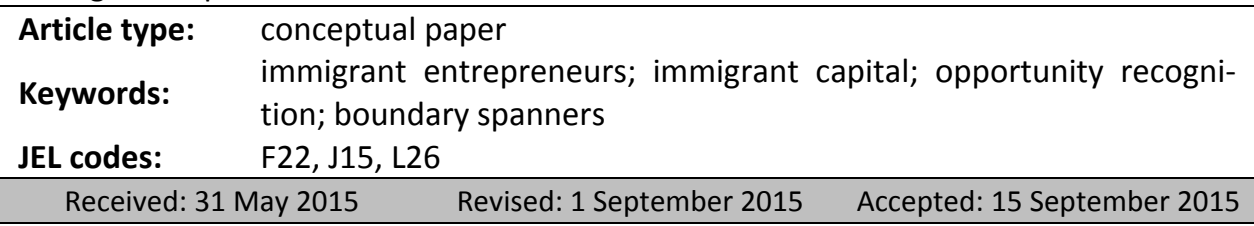

\section{Suggested citation:}

Sundararajan, M., \& Sundararajan, B. (2015). Immigrant Capital and Entrepreneurial Opportunities. Entrepreneurial Business and Economics Review,3(3), 29-50. doi: 10.15678/EBER.2015.030303 


\section{INTRODUCTION}

Numerous theories have been used to explain the relationship between immigration and entrepreneurship. According to the Kauffman foundation's review of the state of this field, the immigrant entrepreneurial activity theories range from intrinsic capabilities of immigrants (human capital), access to social capital, transnational resources, knowledge networks and ready role models as well as host and home country characteristics that lead immigrants to start small businesses. A lack of synthesized and integrated models has, however, led to fragmented understanding of the true drivers of immigrant entrepreneurship, thus making it difficult to repeat the success of immigrants' entrepreneurial activities among host country entrepreneurs. Immigrant entrepreneurship nevertheless continues to be a critical area of study due to the increasing and sustained trends in entrepreneurial activity among immigrants in the United States and Canada as well as other developed nations. For instance, in the United States according to most recent SBA (Small Business Administration) reports (Contreras-Sweet, 2015, p. 1), "immigrant entrepreneurs are twice as likely to start a business as native-born citizens and more importantly, immigrants are actually creating jobs in neighbourhoods where they're needed the most." Further, according to the Fiscal Policy Institute as reported by the current administration, immigrant owned small businesses, with an annual generation of \$776 billion in revenues, employed nearly 4.7 million people in 2007, showing the immense contribution of this sector (Furman \& Gray, 2012). Similarly, in Canada, the first generation total entrepreneurial activity is higher than that of the general population (Langford, Josty \& Holbrook, 2013). Interestingly in Canada, there is a large push in opportunity driven entrepreneurship among immigrants compared to natives (Ibid), which shows that most of immigrants are not turning to entrepreneurship out of necessity but rather out of interest and possibly a greater propensity for being able to recognize business opportunities in comparison to their counterparts in the host country. These sustained immigrant entrepreneurship trends lead us to seek a more robust and comprehensive model that can help us understand why more immigrant and not host country entrepreneurs recognize a higher number of business opportunities.

Entrepreneurship itself, is seen as an activity that involves the discovery, creation and exploitation of opportunities (Shane \& Venkatraman, 2000) wherein a key aspect of being able to perceive entrepreneurial opportunities lies in the access to new information (Arenius \& De Clercq, 2005) as well as the individual's ability to recognize patterns, given that new information (Baron, 2004). Over the past decade, research has found that immigrants and host country entrepreneurs clearly differ in their perceptions of opportunities, as a consequence of which, foreign born individuals are more likely to start companies than their native born counterparts (Fairlie, 2008, Light \& Rosenstein, 1998). This difference in perception and "how" it leads immigrants, compared to natives, to recognize entrepreneurial opportunities and start new ventures forms the crux of our paper. Hence the main objective of our paper is to introduce and operationalize what we term as immigrant capital, which we propose is the key differentiating factor between immigrant and host country entrepreneurs' ability to recognize business opportunities. As we proceed further, founded on the concept of grounded theory, we simultaneously build our theory following the collection and detailed coding of eight U.S. and Canadian 
immigrant entrepreneur case studies, synthesize that information with our literature on immigrant and host country entrepreneurship as well as opportunity recognition drivers, build our theoretical model of immigrant capital and put forth propositions that can be used to test the model in subsequent empirical studies. We summarize our propositions in the discussion section and conclude with implications of the model, limitations of our paper and future research in this area.

\section{MATERIAL AND METHODS}

Opportunity recognition (OR) refers to the active, cognitive processes through which individuals conclude, that they have identified the potential to create something new, that has the potential to generate economic value and is viewed as desirable in the society in which it occurs (Baron, 2004). The most consistent cognitive aspects outlined in the OR literature are prior knowledge and prior experience (Shane, 2000; Shepherd \& DeTtienne, 2005) and psychological factors like motivation, creativity and intention (goals) (Hostager, et al., 1998; Hills, Shrader \& Lumpkin, 1999; Bird, 1992; Krueger, 1993). The empirical studies show that it is either the possession of the above individual characteristics or the access to acquiring them that lead to opportunity recognition. Thus the ability to recognize opportunities has been approached by either directly assessing the entrepreneur's human capital or by resources that support its development, namely, economic, cultural and social capital, as seen from the emphasis on integrated models (Bates, 1997; Pécoud, 2000; Sequeira \& Rasheed, 2006). More recent studies in opportunity recognition vacillate between emphasis on cognitive and emotional mechanisms (Tumasjan \& Braun, 2012; Foo, 2011; Mitchell \& Shepherd 2010; Vaghely \& Julien, 2010; Cardon et al., 2009; Foo, Uy \& Baron, 2009; Baron, 2008; Baron \& Ensley 2006; Cardon et al., 2005) and the access to information through social networks (Kontinen \& Ojala, 2011; Bhagavatula et al., 2010; Ramos-Rodriguez et al., 2010; Ozgen \& Baron, 2007; Puhakka, 2006; Jack \& Anderson, 2002). However, specific to the context of immigrant and host country entrepreneurs, research has indicated that while the motives, attitudes, behaviors and choice of industry vary greatly between different immigrant groups (Masurel et al., 2012; Basu, 1998) and can rarely offer a predictive model of opportunity recognition by themselves, the interaction between these immigrant group characteristics and the opportunity structures in the host country often contribute to increased entrepreneurial activity among immigrants (Waldinger, Aldrich \& Ward, 1990). Subsequent studies (Pécoud, 2000; Marger, 2001) also indicated that it was the immigrants' social, cultural, economic and human capital that led to their access to markets and finance which helped them start companies (Sequeira \& Rasheed, 2006). On the one hand, while human capital (also supported by cultural capital) was good for entry into nascent entrepreneurship and strong social capital helped the immigrants carry the business forward, in the end, it was the act of bridging social ties that proved to be more important than bonding for business (Davidsson \& Honig, 2003). In the above context, bonding occurs between the nodes within a social network whereas bridging occurs between two social networks. In order to build grounded theory, before synthesizing additional concepts from past literature, we first seek to draw codified data from our initial set of case studies from both the U.S. and Canada to help us build our theoretical model. Following which, we will draw out the patterns of activities that have led immi- 
grants to recognize opportunities and start businesses. Founded on these extracted patterns, we develop and propose the immigrant capital model that shows how immigrants are able to recognize a greater number of opportunities compared to host country natives.

\section{Drawing on Codified Data- Data Collection and Analysis of Case Studies of Immigrant Entrepreneurs}

Our research design is based on Glaser and Strauss's (1967) concept of grounded theory, which is a general methodology of analysis linked with data collection that uses a systematically applied set of methods to generate an inductive theory about a substantive theory. Glaser (1992) emphasized the necessity for the researcher to be more creative rather than procedural alone in his or her methodological approach. Hence, founded on the understanding that data collection, analysis and resultant theory generation have reciprocal relationships, as a first step in this process, our paper represents the initial stages in the grounded theory approach to theory development in immigrant capital. In order to facilitate the development of the model, as a pilot study we carried out a series of case study analyses. Eight cases from archived data, were analysed and tabulated to see if there were patterns of unique immigrant characteristics that could contribute to the model of immigrant capital.

We utilized secondary data of select cases from both Canada and the US. Based on the importance placed by the US and Canadian governments' emphasis on immigrants being the driving force of job creation in their economies, for our initial round of data collection, we used a convenience sample from both government websites of immigrant entrepreneurs, who were identified and promoted by their respective governments as success stories. The immigrant entrepreneurs in Canada were winners of the top 25 immigrant awards in the year 2013. The US immigrant entrepreneurs were the success stories of immigrant entrepreneurs followed by the Massachusetts State. We selected four cases from each country.

\section{Methodology}

We categorized each case's content into human, cultural, economic and social capital available to the respective immigrant. We also added two measures to capture the number of cross-country networks the immigrant entrepreneurs were boundary spanners of, and the type of nodes they seemed to have access to, which would have enabled them to recognize the opportunity and start their companies.

\section{Synthesis of Findings with literature to develop theory and model of Immigrant Capital}

Based on our analysis, we identified as shown in the tables (please refer A3 tables 1 and 2), two distinct patterns. One that the number of networks they were part of was by default two or more. Second, the nodes or dots they identified and connected with, which led to the recognition of their business opportunity and establishment of their company, were from multiple cross-country networks, both in the US and Canada. These patterns are only preliminary in their assessment but allow us to build the theory further as we revisit the literature in this area. 
Table 1. United States Case Studies of Immigrant Entrepreneurs as boundary spanners

\begin{tabular}{|c|c|c|c|c|}
\hline Host Country & \multicolumn{4}{|c|}{ USA } \\
\hline Company Name & Swissbakers & Ultra Beauty Salon & Boston Bio-medical & $\begin{array}{c}\text { Zumi's Espresso and Ice } \\
\text { Cream }\end{array}$ \\
\hline Company Product & Bakery items & Beauty Services & $\begin{array}{l}\text { Biomedical } \\
\text { research }\end{array}$ & Food Services \\
\hline Country of Origin & Switzerland & Dominican Republic & China & Nepal \\
\hline Human Capital & $\begin{array}{c}\text { Knowledge of baking, } \\
\text { Passion, Diligence, English } \\
\text { Language }\end{array}$ & $\begin{array}{c}\text { Family Values, acquired } \\
\text { Cosmetology knowledge, } \\
\text { Creative }\end{array}$ & $\begin{array}{l}\text { Medical Higher Education } \\
\text { Knowledge of English } \\
\text { Occupation }\end{array}$ & $\begin{array}{l}\text { Unrelated prior knowledge } \\
\text { (outdoor sports) }\end{array}$ \\
\hline Cultural Capital & $\begin{array}{c}\text { Language, Family values, } \\
\text { More accepted with } \\
\text { European accent }\end{array}$ & Hard work, family business & $\begin{array}{c}\text { Experience of a poor } \\
\text { country and grew up in a } \\
\text { cultural revolution }\end{array}$ & $\begin{array}{c}\text { Grew in a mountain village } \\
\text { with farmers in country of } \\
\text { origin }\end{array}$ \\
\hline Economic Capital & Personal funds & Personal funds & $\mathrm{n} / \mathrm{a}$ & $\mathrm{n} / \mathrm{a}$ \\
\hline Social Capital & $\mathrm{n} / \mathrm{a}$ & & & \\
\hline $\begin{array}{c}\text { Number of Cross-cultural } \\
\text { networks as boundary } \\
\text { spanners }\end{array}$ & $\begin{array}{l}\text { Multiple in Europe and US } \\
\text { cultures }\end{array}$ & $\begin{array}{c}\text { In Dominican, Hispanic and } \\
\text { US cultures }\end{array}$ & China, Japan, USA & Nepal, UK, USA \\
\hline $\begin{array}{l}\text { Types of Nodes } \\
\text { (Dots) Connected }\end{array}$ & $\begin{array}{l}\text { Difference in ways of } \\
\text { eating in the two cultures, } \\
\text { brought European lifestyle } \\
\text { to USA, thus saw an } \\
\text { opportunity to serve } \\
\text { American Community }\end{array}$ & $\begin{array}{c}\text { Understood the need of } \\
\text { Hispanic community to } \\
\text { have a Hispanic } \\
\text { hairdresser, In US it was } \\
\text { either Caucasian or African } \\
\text { American salons. Only two } \\
\text { salons in Boston, so saw an } \\
\text { opportunity to serve } \\
\text { ethnic community }\end{array}$ & $\begin{array}{l}\text { Saw need for extensive } \\
\text { Cancer Research and } \\
\text { capitalized entrepreneurial } \\
\text { ambition to be a scientist } \\
\text { in America due to its host } \\
\text { country characteristics } \\
\text { allowing the pursuit of } \\
\text { such endeavors }\end{array}$ & $\begin{array}{c}\text { For Coffee Shop, knew } \\
\text { farmers from Nepal, saw it } \\
\text { was not fresh always in the } \\
\text { US so purchased directly } \\
\text { from farmers in Nepal. Felt } \\
\text { US was a great place to } \\
\text { provide awareness for } \\
\text { human rights so practiced } \\
\text { as US supported it }\end{array}$ \\
\hline
\end{tabular}

Source: http://www.ilctr.org/promoting-immigrants/immigrant-entrepreneurship/video-interviews/

as US supported it 
Table 2. Canadian Case Studies of Immigrant Entrepreneurs as boundary spanners

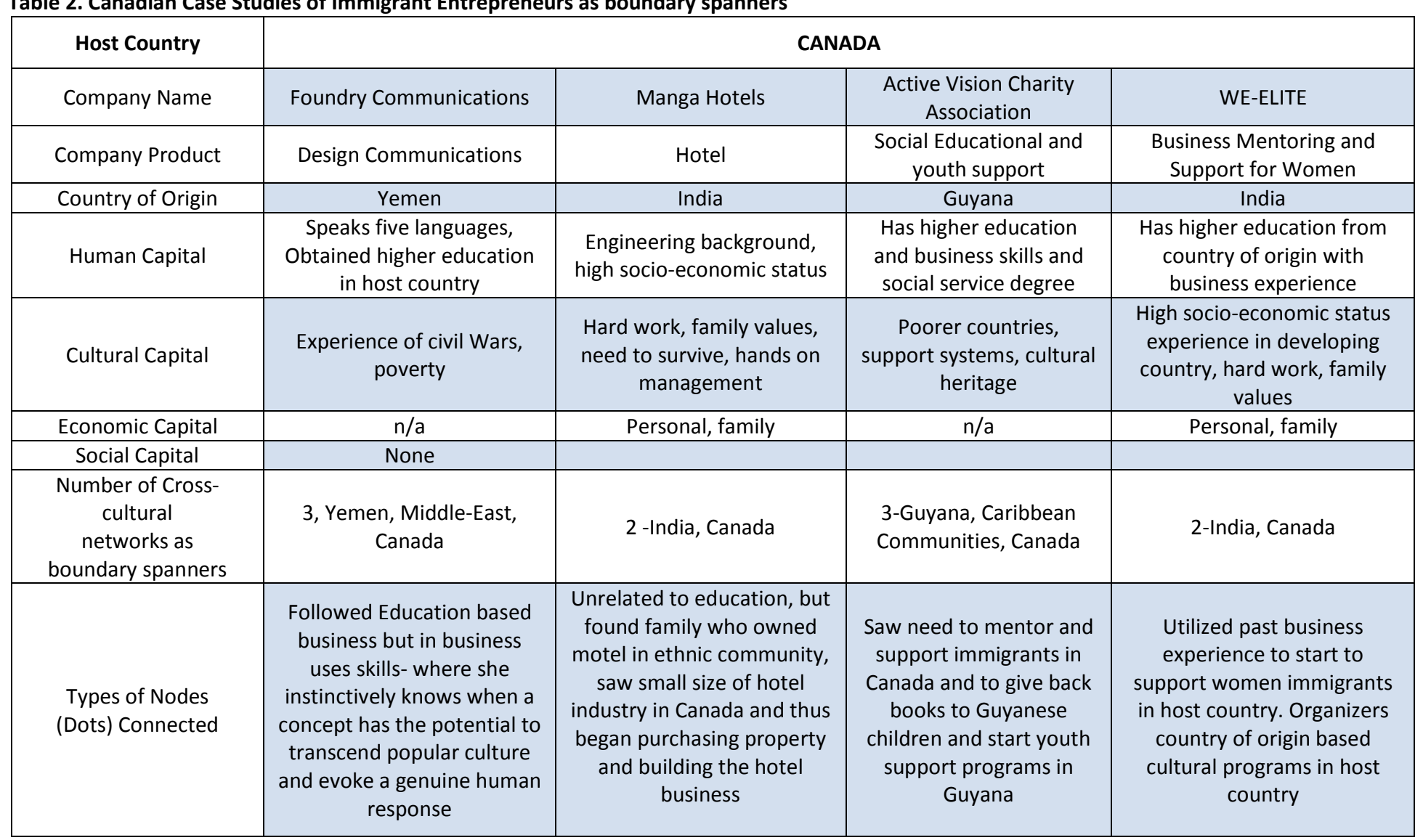

Source: http://canadianimmigrant.ca/canadas-top-25-immigrants/canadas-top-25-immigrants-2013 


\section{LITERATURE REVIEW AND THEORY DEVELOPMENT}

An important observation from our case analyses is the presence of a process of association of information from multiple sources given their vantage point across different networks. This observation is substantiated by research in the opportunity recognition literature (Vaghely \& Julien, 2010; Baron \& Ensley, 2006). They show that linking patterns of information from various sources forms the basis of innovation and new business opportunities. We also see a definitive emphasis, by opportunity recognition researchers, on the need to concentrate on the process of how opportunity recognition takes place rather than just the characteristics of the individual (Davidsson \& Honig, 2003; Ardichvili, Cardozo \& Ray, 2003). The process itself is shown to entail scanning and search, association and connection and finally the evaluation and judgment (Tang, Kacmar \& Busenitz, 2012). Hence, investigating these concepts further, we find that entrepreneurship involves the nexus of opportunities and enterprising individuals (Shane \& Venkataraman, 2000) but at the same time, the process of opportunity recognition is a function of genetic and environmental factors (Nicolaou \& Shane, 2009). Further, immigrant entrepreneurship literature shows that interaction between opportunity structures and immigrant group characteristics as well as their ethnic strategies is complex but relevant because the changing opportunity structures present different market conditions (Waldinger, Aldrich \& Ward, 1990) which will impact the business opportunity recognition process. The greatest weight although, has been given to the immigrant's social capital and how they are able to access new information (Zhou, 2004; Jack \& Anderson, 2002; Ndoen et al., 2000).

Thus not surprisingly, to understand the immigrant entrepreneur's trends, researchers have observed that it could be a combination of social, cultural, economic and human capital (Bates, 1997; Pécoud, 2000; Sequeira \& Rasheed, 2006) that helps immigrant entrepreneurs recognize opportunities and successfully start new ventures. This alone, however, cannot help explain the immigrant entrepreneur's ability to start more businesses than host country entrepreneurs because, host country entrepreneurs are equally aware of their own countrymen's cultural needs and requirements, have substantial social, human, cultural and economic capital and yet, immigrants are seen to be twice as likely to start new businesses as natives (Contreras-Sweet, 2015). Thus even though the debate about what leads immigrants to recognize more entrepreneurial opportunities than natives remains ongoing (Light, 2014), it has become critical to develop a more complete theory of immigrant entrepreneurship through the integration of the four kinds of capital namely, social, cultural, human and economic (Sequeira \& Rasheed, 2006) to be able to learn from and replicate the sustained success of immigrant entrepreneurial activity. The support to derive an integrated model can also be seen in the opportunity recognition literature, which states, not only are entrepreneurial opportunities recognized from individual's differential access to information (Kirzner, 1973) but entrepreneur's must be able to recognize the value of any new information to which they are exposed (Shane, 2000). This also means that the ability to recognize patterns and connect the dots becomes a critical distinguishing factor between entrepreneurs and non-entrepreneurs (Baron \& Ensley, 2006). Proceeding further, we explore each of the 
factors identified to be critical for opportunity recognition and immigrant entrepreneurs to aid the development of the concept of immigrant capital.

\section{Human Capital, Opportunity Recognition and Immigrant Entrepreneurship}

When developing an opportunity recognition model based on human capital (in this paper, we conceptualize this as all individual characteristics that contribute to their skills, knowledge and abilities) we note that the strongest empirical evidence has been for prior knowledge and experience in relation to individual cognitive processes (Shane 2000; Simon, Houghton \& Aquino 2000; Shepherd \& Detienne, 2005; Baron \& Ensley, 2006). Prior knowledge of a particular market helps entrepreneurs recognize opportunities more easily (Shane, 2000). Specific to the case of immigrant entrepreneurs, research shows that higher educational attainment in their country of origin, prior to immigrating, and that acquired in the host country, contribute to greater entrepreneurial activity among immigrants (Arenius \& De Clercq, 2004; Razin \& Scheinberg, 2001; Froschanuer, 2001; Bates, 1994; Becker, 1964). Additionally, prior experience in the form of being selfemployed in their country of origin has also been shown to increase the likelihood of immigrants being self-employed in host countries (Akee, Jaeger, \& Tatsiramos, 2007). Prior experience in an occupation also led to developing businesses in the same field (Cooper \& Dunkerberg, 1986). We summarize, with respect to human capital, that immigrant entrepreneurs are able to recognize opportunities better than others using cognitive schemas or learning, obtained from prior experience (from prior self-employment) and knowledge (from higher educational attainment). Since, natives can also have all of the above characteristics, the question still remains, "why are immigrants more likely to start new businesses than natives". What other factors could be at play here?

\section{Cultural Capital, Opportunity Recognition and Immigrant Entrepreneurship}

With reference to cultural capital, compared to natives, first generation immigrants remain embedded in their original country's culture despite the influence of the host country's cultural environment (Hofstede et al., 2004), hence making it equally important to view entrepreneurship as a function of cultural perception of opportunities (Dana, 1996). Early research in this topic showed that the entrepreneurial propensity is based on national origin, national culture and religious notions (Aldrich, 1990), which we refer to as their cultural capital in this paper. The immigrant's cultural knowledge in the use of their mother-tongue in marketing their business is also viewed as an additional advantage (Barett, Jones \& McEvoy, 2003). Another important differentiating cultural factor is that, immigrants from countries with low power distance are more likely to become entrepreneurs (Vinogradov \& Kolvereid, 2007). On the other hand, in certain countries like Algeria, family is viewed to be detrimental in the development of entrepreneurial intention of women entrepreneurs (Benhabib et al., 2014). As already noted above, immigrants from countries with a greater number of self-employed people are more likely to be selfemployed in host countries, (Akee, Jaeger, \& Tatsiramos, 2007). However, when we summarize the findings, we understand that it is not about different cultures, but the different ways of mobilizing and using resources in different cultures and the different 
ways of linking culture to action that adds value to an immigrant entrepreneur's cultural capital (Swidler, 2001).

\section{Economic Capital, Opportunity Recognition and Immigrant Entrepreneurship}

Economic capital or access to financial resources will undoubtedly play a deciding role in whether or not, an immigrant is able to start a new venture in the host country (Marger, 2001; Stark \& Wang, 2002, SBA Report, 2012). Research has, likewise, shown that in addition to educational attainment, large investments do indeed play a role in the success of immigrant entrepreneurs (Bates, 1994). In fact, when immigrants come from higher economic classes, their better access to financial access (through their strong family ties and trust networks)increases their likelihood of entrepreneurial activity and success (Zhou, 2004). Those with high socio-economic status with access to greater human, social and investment capital as well as business support, have greater success as entrepreneurs (Anderson \& Miller, 2003). While, this is impressive, it is once again not unique to immigrants, and therefore still fails to address the key differentiating factor in entrepreneurial activity.

\section{Social Capital, Opportunity Recognition and Immigrant Entrepreneurship}

A strongly emphasized area with respect to the ability of immigrants to recognize opportunities is their social capital. Research shows that immigrants and natives, differ in their perceptions of opportunities because of difference between the networks they are embedded in and nature of one's residential area (Arenius \& De Clercq, 2004). An immigrant's social capital has been studied as the various ties or relations they have in their host and home countries (Zhou, 2004; Jack \& Anderson, 2002). When immigrants forge and sustain multi-stranded relations that link together their societies of origin and settlement, the resultant social capital (network) is defined as transnationalism (Basch, Schiller \& Blanc, 1994). When the immigrants' group membership is tied to a common cultural heritage, intrinsically intertwined in particular social structures in which individual behavior, social relations and economic transitions are constrained, it is referred to as ethnic enclaves (Zhou, 2004). Enclave entrepreneurs include those who are bounded by co-ethnicity, co-ethnic social structures and location. Even though early studies about the effects of social capital on immigrant populations were around the job search and ethnic segmentation in labor markets (Sanders, Nee \& Sernau, 2002) or even the establishment of trust and cooperation (Portes \& Sensenbrenner, 1993), studies about transnational ties and ethnic enclaves offer support for what is often highlighted in social capital literature as the key purpose of networks in entrepreneurial activities, i.e. access to other resources (Aldrich \& Zimmer, 1996). For instance, access to unknown and new opportunities through structural holes (Burt, 2009) or networks that create new knowledge and help with exchange of knowledge (Nahapiet and Ghoshal, 1998) or networks which are a source of new ideas (Christenson \& Peterson, 1990) and new opportunities (Singh et al., 1999) with access to knowledge the immigrant entrepreneur does not currently possess. A search for patterns with respect to the distinct advantage that an immigrant entrepreneur has over his/her counterpart showed that, whatever their ethnicity, all immigrants' association networks tend to mix socializing with support for 
professional and technical advancement. The willingness to mentor new incumbents, share knowledge and experience, to provide contacts for new businesses all act as a definite advantage for the new immigrant entrepreneur, hence, enabling continuous knowledge flow among community members, mentor-apprentice relationships in the networks; and access to contacts through trusted networks (Saxenian, 2002).

However, opportunity recognition literature has shown that having access to information alone does not lead to opportunity recognition, rather that opportunities are identified only when people formulate a new means-ends framework in response to that new information utilizing associated thinking and more diverse knowledge and information (Dyer, Gregersen \& Christensen, 2008).

To understand how immigrants formulate this new means-ends framework, we build upon the research findings of social capital and integrate it with the concepts put forth by immigrant entrepreneurship researchers with respect to opportunity structures (Waldinger, Aldrich \& Ward, 1990); the co-ethnic structures of ethnic enclaves (Zhou, 2004) and value of being embedded in local social structures (Jack \& Anderson, 2002).

It must be noted that studies related to transmigrants, i.e., immigrants who make decisions, take actions, and develop identities in social networks that connect them to two or more societies simultaneously (Schiller, Basch \& Blanc-Szanton, 1992), address a similar concept of access to different types of capital and its value to the immigrant's country of origin. Our paper, however, is very different in its aim, as it identifies the unique capability of immigrant entrepreneurs both within and outside the host country and how this capability differentiates them from the natives, who have access to similar sources of capital. As we proceed to develop the model, we will funnel in on the uniqueness of the capital possessed by immigrants when compared to their host country counterparts and then propose the model and its propositions.

\section{Development of the Concept, Definition and Operationalization of Immigrant Capital}

Recent studies have begun identifying that it may indeed be the immigrant entrepreneur's outsider status that allows them to recognize, "out of the box" opportunities that natives with similar knowledge and skills cannot perceive (Hart, Acs \& Tracy, 2009). The immigrant's capabilities may be linked to unique entrepreneurial resources, like access to partners, customers and suppliers in their countries of origin.

Initial studies (Pécoud, 2000; Marger, 2001) indicated that it was the immigrants' social, cultural, economic and human capital that led to their access to markets and finance which helped them start companies (Sequeira \& Rasheed, 2006). Yet the model fails to account for the fact that natives also possess similar capital resources (Figure 1).

Thus, in creating an integrated theory of immigrant entrepreneurship, we must consider immigrant capital as not just moderating the relationships, but being a prime mover that leads to immigrant entrepreneurial opportunity recognition and venture creation processes.

Even though individuals access to external knowledge through social networks in which they participate is shown to be fundamental for developing the capacity to recognize new business opportunities (Ramos-Rodriguez et al., 2010), the quality of the network contacts is equally important (Hills, 1995). In social networks while we hope the individual's contacts (nodes) will do the work of being in different places at the same 
time and providing access to that information and resource to the immigrant (Bhagavatula et al., 2010), it is imperative to acknowledge that different people perceive different values of the same information thus leading to differences in identifying opportunities (Shane, 2000). So in this case, although the individual has access to multiple contacts and their information, it would not be able replace the individual's direct presence in multiple networks. This is in alignment with another key point that we observed in our cases, which was, the immigrant entrepreneurs' position as boundary spanners in multiple cross-country social networks and "their" perception of novel business opportunities which they perceived through associated thinking.

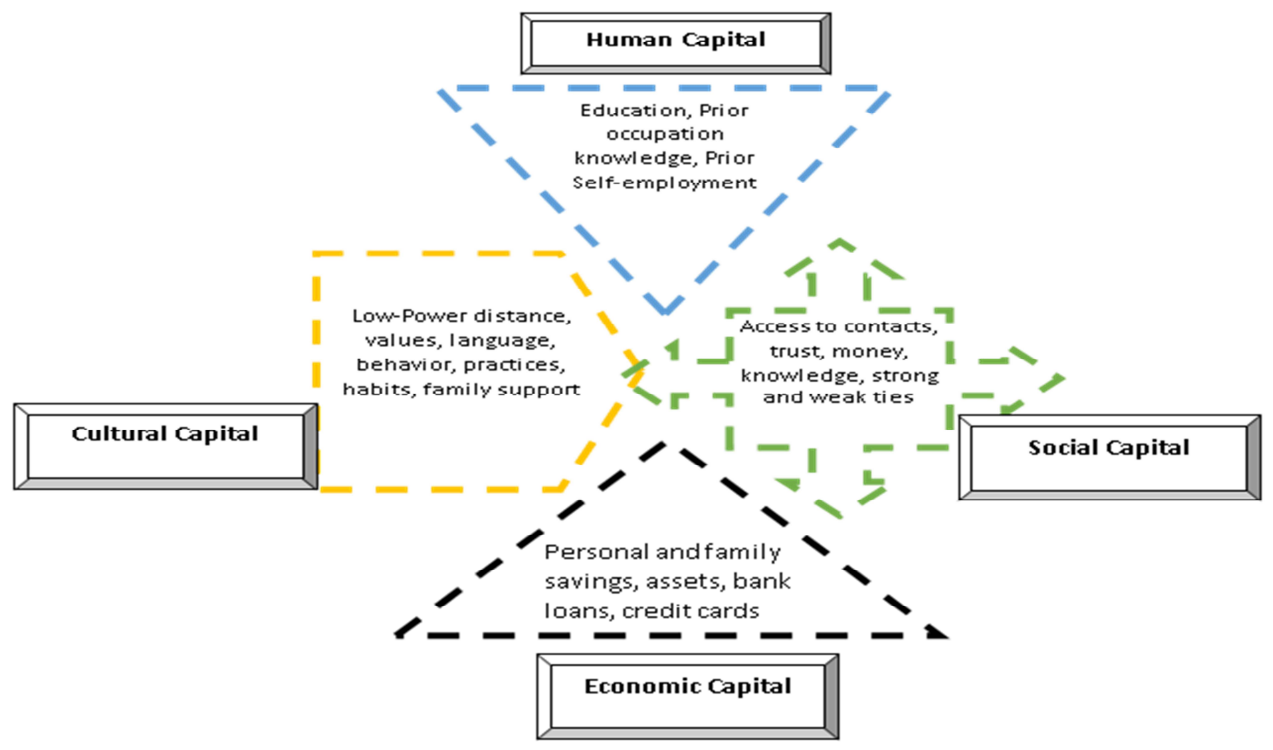

Figure 1. Four forms of capital available to Immigrant and native entrepreneurs Source: own elaboration.

\section{The Immigrant Capital Model}

Thus, immigrant entrepreneurs in addition to all four types of capital, possess a unique perspective to view the cross-country needs within and outside their ethnic enclaves. They obtain this uniqueness due to two reasons. The first, is their position as boundary spanners in multiple networks. Boundary spanners, by virtue of their position in and across networks, have the ability to not only connect an organization or group to the external environment, but also have the ability to influence the decisions, processes and information flowing between the internal and external networks. They thus become the harbingers of potential risks and opportunities existing across diverse networks. Friedman and Podolny (1992) explain that past research indicates, how boundary spanners are important for conducting exchange between groups for international diplomacy and for communication between ethnic groups.

However, the manner in which this occurs is in essence a distillate of the immigrant's human, cultural, social and economic capital, which is the second and most important reason for an immigrant entrepreneur's uniqueness. As illustrated in the figure 2, we 
realize the unique differentiating factor between immigrants and natives, is not only their position as boundary spanners in multiple, diverse cross-country networks, but the access they have to a greater number of nodes (with new knowledge, skills, money, experience, contacts and support) that increase the probability of immigrants to connect a greater number of dots (nodes) enabling them to recognize more entrepreneurial (business) opportunities, compared to natives.

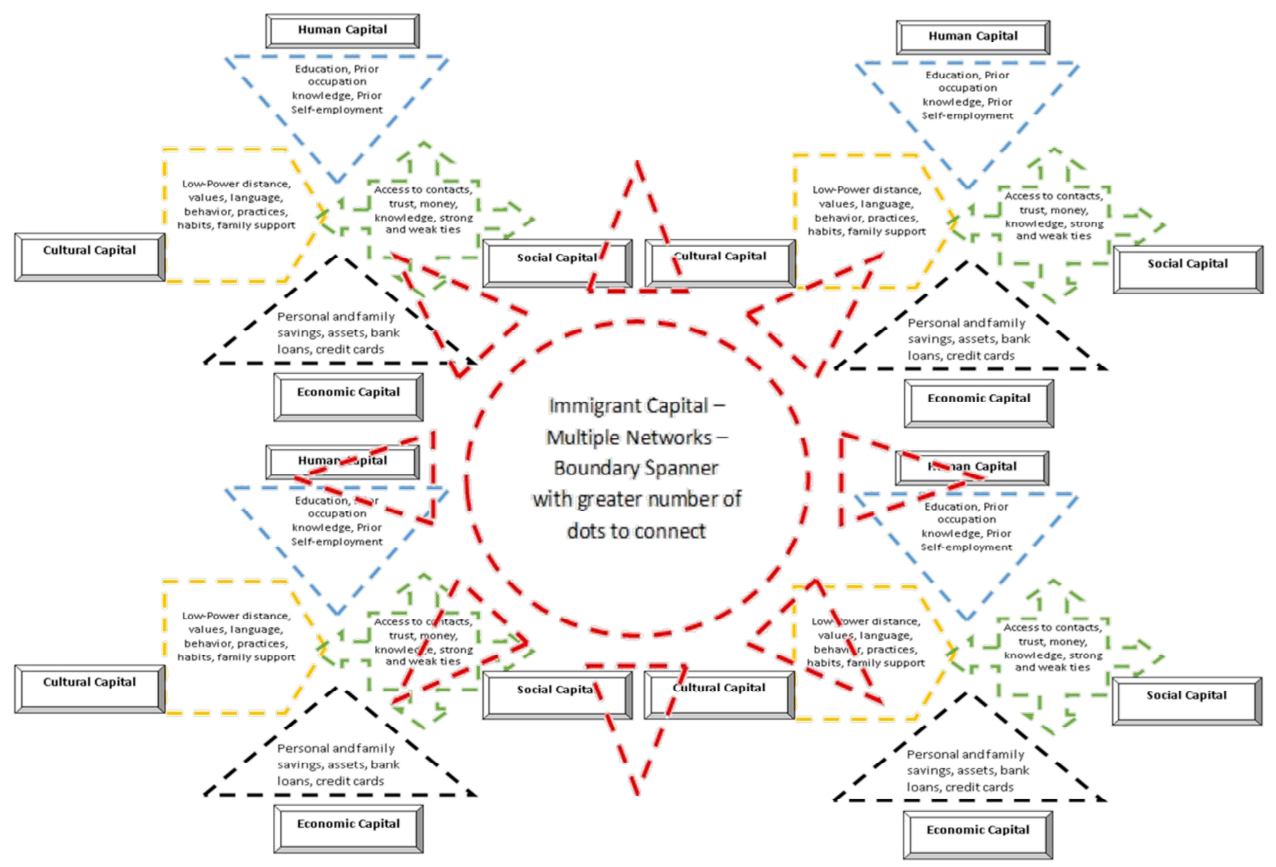

Figure 2. Formation of Immigrant Capital by being boundary spanners in multiple networks with access to greater number of nodes or dots that they can connect, thus leading to greater ability to recognize opportunities Source: own elaboration.

Being embedded in the social structure creates opportunities and improves performance because embedding enables the entrepreneurs to use the specifics of the environment. Still, the opportunity creation is in turn also influenced by the immigrant's role in the social network when they become part of the local structure (Jack \& Anderson, 2002). So when an individual has multi-positional multi-network embeddedness, they are able to draw upon and use resources that help create opportunities which can fit the specific needs of each of those networks (i.e. for the local situation, the ethnic enclaves and a niche market) hence giving rise to a higher number of potential business opportunities compared to natives who would be embedded only in their local social structures.

As explained by Jack and Anderson (2002) the process of opportunity recognition is thus much more than just developing social networks. Studies explain, that new information is often shared only by personal relations in certain countries' social networks (Puhakka, 2006). Further, entrepreneurs who recognize opportunities seem to organize prior knowledge and information in a way that is easily accessible to them, and therefore 
have confidence in using weak and strong ties to see opportunities in environment (Riquelme, 2013).

Based on Jack and Anderson's (2002) model we suggest, that by being boundary spanners embedded in multiple countries' social structures, it makes it easier for the immigrant entrepreneurs to understand what is required and available in the various markets. Once the immigrant entrepreneurs understand the nature of the structure,it allows them to enact or re-enact this structure which forges new ties and maintain both the links and structure across different social structures, thus extracting and producing value from and to the local, ethnic and cross-country structures.

Hence, we call this pattern 'immigrant capital' and posit that it is culled from all four forms of capital. This dual or multiple sided perspective, provides the immigrant entrepreneur the distinct advantage of having a cross-country cognitive schema. They begin connecting the dots, wherein the dots are represented by independent nodes of information available in their network environments, by understanding the needs of the ethnic and host communities as well as the gaps in the market which failed to serve one or both communities. With ethnic communities it is products from their country of origin, products in the local market with an added cultural value and services that support new immigrants. For host country communities it may be offering products that can be exciting due to the novelty of the product or services' cross-country element or the lowered price due to its outsourced/imported nature, or even a product or service based on one's high educational knowledge, otherwise lacking in the host country, native born individuals.

What we observe is, that to succeed in their venture, the immigrant will actively seek the participation of boundary spanners in the community, or themselves become the boundary spanners, so as to obtain access between adjoining cross-country enclaves as well as the broader host society and therefore be more attuned to cross-country opportunities. We thus define immigrant capital as follows:

Immigrant capitalist the ability of an immigrant to actively seek and embed themselves in boundary spanner positions in cross-country networks in such a manner so as to facilitate the development of cross-country cognitive schemas that provides access to a greater number of network nodes, which provide access to diverse information that can be connected, enabling immigrant entrepreneurs to recognize opportunities better than the natives.

We operationalize immigrant capital in terms of measuring it by the number of different country networks the immigrant is a boundary spanner of and the number of nodes (dots) in the form (type) of knowledge, access to new information, selfemployment experience, money and contacts available to them in those networks. Based on the above model, we thus put forth the following three propositions to differentiate immigrant entrepreneur's opportunity recognition ability from that of host country entrepreneurs.

Proposition 1: Immigrants, who have access to social, cultural, human and economic capital and who actively seek boundary spanner positions in cross-cultural networks, will be able to better demonstrate (than the other immigrants) the phenomenon of immigrant capital, as they seek to recognize opportunities and start entrepreneurial ventures. 
Proposition 2: Immigrants with greater immigrant capital in the form of being boundary spanners in two or more cross-country embedded social networks, with access to a greater number of dots, will recognize a higher number of entrepreneurial opportunities than host country entrepreneurs.

Based on our grounded theory approach, the reemphasis on concentrating on the process, shows that the integration of human capital and social network concepts supported by access to cultural and economic resources leads to an enhanced ability in immigrants to recognize opportunities and create ventures. First from the human capital side, studies show that opportunity images of experienced entrepreneurs focus on profitability, feasibility and awareness of their respective environments (Baron \& Ensley, 2006). But, those with a self-image of vulnerability where they have a higher fear of failure may be less likely to differentiate between environments that can and cannot benefit their venture compared to those that have a self-image of enhanced capability (Mitchell \& Shepherd, 2010). So, from a human capital perspective it is helpful to have greater entrepreneurial self-efficacy and an ability to connect the dots. From a social capital perspective, we acknowledge studies have shown that entrepreneurs with higher generalized trust and the breadth of formal organizational memberships are more likely to perceive entrepreneurial opportunities (Kwon \& Arenius, 2010) or that strong ties lubricate the economic transactions of a venture and increase its chances of success in performance (Bhagavatula et al., 2010). Similarly, as explained previously, both cultural (Dana, 1996) and financial support (Marger, 2001; Stark \& Wang, 2002; SBA Report, 2012) play a significant role in going beyond the point of recognizing opportunities and supporting the creation of new ventures. We thus propose that:

Proposition 3: Immigrant entrepreneurs with greater immigrant capital in the form of being boundary spanners in two or more cross-country embedded social networks, with access to economic, human and social capital will be more successful in starting their new ventures than host country entrepreneurs.

As part of the continuing process of building our theoretical model, to test these propositions, in the future, we plan to collect three different forms of data, one-to-one interviews with successful immigrant entrepreneurs and host country entrepreneurs, survey data of host country and immigrant entrepreneurs and archived stories from newspapers or magazines describing successful immigrant and host country entrepreneurs. Such a combination of one-to-one interviews and network surveys will help identify not only the structural positions that successful immigrant entrepreneurs occupy in cross-country networks, but possibly confirm that they are indeed occupying boundary spanning positions in these networks. Survey data and archived data analysis will further help triangulate the findings and allow the testing of these propositions as hypotheses.

The interview data and archived data will both be coded using researcher constructed categories (Douglas, 2003). These codes will follow both an open coding approach, as well as a thematic code category approach. The thematic code categories will be as depicted in the figure 3. As we indicated earlier, immigrant capital is a distillate of social capital, economic capital, cultural capital and human capital and the network positions assumed and adopted by immigrant entrepreneurs, arising from their networking activities and their network capital will likely give them prominence, allow them to occupy 
boundary spanning positions across cross-country networks and bridge structural holes across networks (Burt, 2009) leading them to recognize opportunities earlier than other host country entrepreneurs.

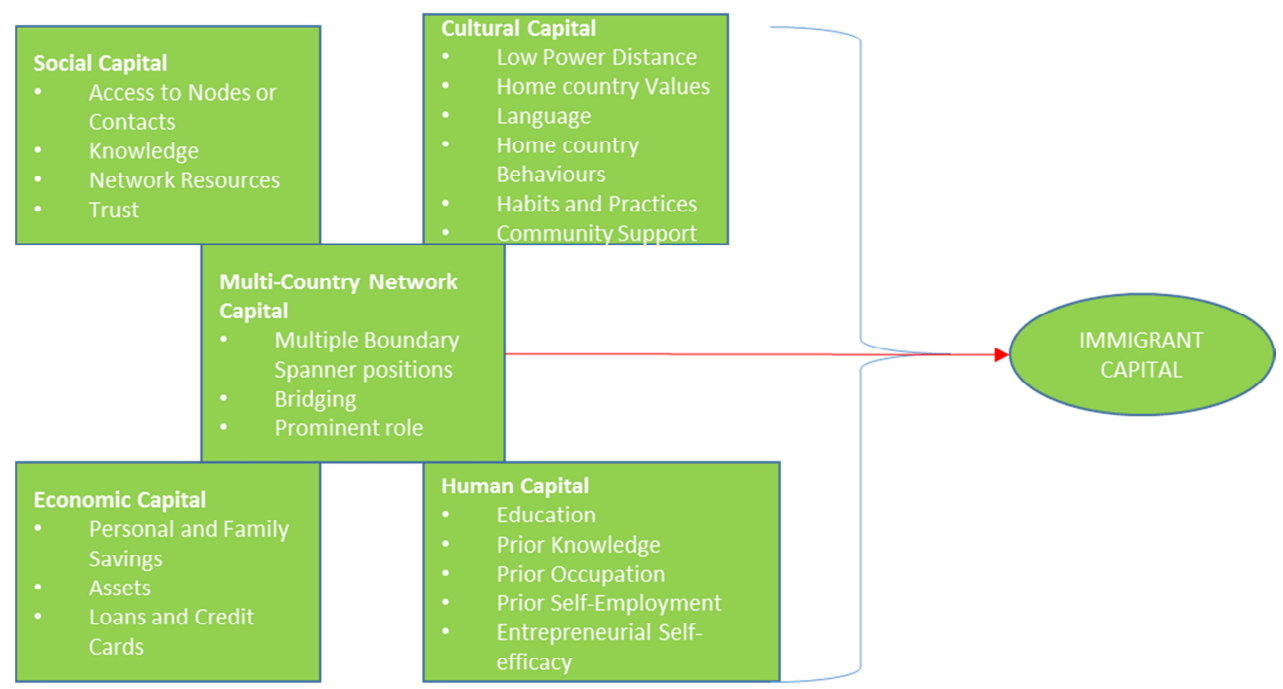

Figure 3. The thematic code categories to measure immigrant capital as a distillate of different opportunity recognition and venture creation driving factors

Source: own elaboration.

\section{CONCLUSIONS}

Our paper, utilizing the process of grounded theory, synthesized current immigrant entrepreneurship literature with coded data collected from archived secondary case data to propose a model of immigrant capital that explain why immigrants and not natives display a higher rate of entrepreneurial activity. Considering that class and level of education of all immigrant groups are subjected to different economic and social influences, we cannot expect a simple universal panacea to describe entrepreneurial activity among different immigrant entrepreneur groups (Ibrahim \& Galt, 2003). However, adopting Singh's (2001) view of entrepreneurial opportunities as feasible, profit-seeking, potential ventures that provide an innovative new product or service, or those that imitate a profitable product/service in a less than saturated market, we get a broad enough definition that allows us to include incremental and radical products/services and all in between, giving us a large group of immigrant small businesses that sell such products to study when we develop our model further. While we acknowledge the actual success and failure of the firm is influenced by several other factors not considered in this paper, we feel our model helps pool several fragmented concepts in the immigrant entrepreneurship literature thus providing a much stronger foundation to build upon when exploring immigrant opportunity recognition and venture creation abilities.

The most significant contribution of this proposed model is, how countries experiencing economic downturns can learn from immigrant entrepreneurs, who have exhibit- 
ed a consistent pattern of growth and success utilizing their cross-country schema based immigrant capital. Both, academic and industry experts, can design and develop training programs that show nascent entrepreneurs, how to become multi-country boundary spanners and hone their opportunity recognition abilities. Host country entrepreneurs can also be trained to see how they can capitalize on regional differences and learn to recognize gaps in the market to serve the needs of natives who are from different regions within the country as well as globally. An interesting area of application is in international joint ventures, because while weak ties have been shown to help with opportunity recognition internationally, the nature of the cooperators play a critical role in the development of the business (Kontinen \& Ojala, 2011). This can also be addressed with the embedded multi-country boundary spanner oriented training programs. The contribution of this model to the academia will support proactive training of potential immigrants as well as native entrepreneurs. For instance, a constructive academic application could be, a course in entrepreneurship which can have any host country students form groups with virtual teams from different nations from around the world and have the instructor walk them through the process of building immigrant capital if they were to start a business in other countries.

\section{Limitations And Suggestions For Future Studies}

Being a theoretical paper focused on the development of a much needed concept to address the gap in immigrant entrepreneurship, an important limitation is the validation needed by comprehensive primary data sources. While we have begun this study based on a convenient sample of case studies as part of our initial pilot study as discussed above, we are in the process of seeking large data to test the model and refine it accordingly to continue building a grounded theory of immigrant capital. We are also limited in our ability to compare and generalize much of the empirical findings because most of them are country specific and home country characteristics and host country's market conditions offer varied permutations and combinations that differ from country to country and one immigrant group to another. We hope, however, with a more common model and concept, it would help begin a fresh series of comparable studies and findings, helping our field more constructively.

Further studies need to focus on empirical data from countries across the globe, to investigate the extent to which immigrant capital impacts the outcome of the entrepreneurial ventures for both immigrants and natives. Another area of interest is the parsing of the home country value system of immigrant entrepreneurs from third world countries and its interactive effects with immigrant identity. There is a tight value system of education, thrifty living, hard work, persistence and family first behavior from collectivist societies that sustain entrepreneurial activities of immigrants if they identify themselves that way. Integrating such a value system with the identity of natives, into the systemic development of a universal entrepreneurial process can only benefit small businesses in a struggling economy. 


\section{REFERENCES}

Akee, R., Jaeger, D. A., \& Tatsiramos, K. (2007). The persistence of self-employment across borders: New evidence on legal immigrants to the United States. Available at SSRN 1136412.

Aldrich, H. E. (1990). Using an ecological perspective to study organizational founding rates. Entrepreneurship Theory and Practice, 14(3), 7-24.

Aldrich, H. E., \& Zimmer, C. (1986). Entrepreneurship through Social Networks, University of Illinois at Urbana-Champaign's Academy for Entrepreneurial Leadership.

Anderson, A. R., \& Miller, C. J. (2003). Class matters: human and social capital in the entrepreneurial process. Journal of Socio-Economics, 32(1), 17-36.

Ardichvili, A., Cardozo, R., \& Ray, S. (2003). A theory of entrepreneurial opportunity identification and development. Journal of Business Venturing, 18(1), 105-123.

Arenius, P., \& De Clercq, D. (2005). A network-based approach on opportunity recognition. Small Business Economics, 24(3), 249-265.Arenius, P \& De Clercq, D (2004). A network based approach to opportunity recognition, Vlerick Leuven Gent Working Paper Series, 2004/23

Baron, R. A. (2004). The cognitive perspective: a valuable tool for answering entrepreneurship's basic "why" questions. Journal of Business Venturing, 19(2), 221-239.

Baron, R. A. (2008). The role of affect in the entrepreneurial process. Academy of management Review, 33(2), 328-340.

Baron, R. A., \& Ensley, M. D. (2006). Opportunity recognition as the detection of meaningful patterns: Evidence from comparisons of novice and experienced entrepreneurs. Management science, 52(9), 1331-1344.

Barrrett, G.A., Jones, T.P., \& McEvoy, D. (2003). United Kingdom: severely constrained entrepreneurialism. In R. Kloosterman \& J. Rath (Eds.), Immigrant entrepreneurs: venturing abroad in the age of globalization. Oxford: Berg.

Bash, L., Glick Schiller, N., \& Szanton Blanc, C., (1994). Nations Unbound: Transnational Projects: Postcolonial Predicaments and Deterritorialized Nation-States. Amsterdam: Gordon \& Breach.

Basu, A. (1998). An exploration of entrepreneurial activity among Asian small businesses in Britain. Small Business Economics, 10(4), 313-326.

Bates, T. (1997). Financing small business creation: The case of Chinese and Korean immigrant entrepreneurs, Journal of Business Venturing, 12(2), 109-124.

Becker, G.S. (1964). Human Capital, Chicago, University of Chicago Press.

Benhabib, A., Merabet, A., Benachenhou, M., Grari, Y., Boudia, F. \& Merabet, H. (2014). Environmental and Individual Determinants of Female Entrepreneurship in Algeria: Applying the Structural Equation Modeling, Entrepreneurial Business and Economics Review, 2(1), 65-80

Bhagavatula, S., Elfring, T., van Tilburg, A., \& van de Bunt, G. G. (2010). How social and human capital influence opportunity recognition and resource mobilization in India's handloom industry. Journal of Business Venturing, 25(3), 245-260.

Bird, B. J. (1992). The Roman God Mercury An Entrepreneurial Archetype. Journal of Management Inquiry, 1(3), 205-212.

Burt, R. S. (2009). Structural holes: The Social Structure of Competition. Harvard University Press.

Cardon, M. S., Wincent, J., Singh, J., \& Drnovsek, M. (2009). The nature and experience of entrepreneurial passion. Academy of Management Review, 34(3), 511-532. 
Cardon, M. S., Zietsma, C., Saparito, P., Matherne, B. P., \& Davis, C. (2005). A tale of passion: New insights into entrepreneurship from a parenthood metaphor. Journal of Business Venturing, 20(1), 23-45.

Christenson, P.S., \& Peterson, R. (1990) Opportunity Recognition: Mapping the Sources of New Venture Ideas. Paper presented at the 10th annual Babson Entrepreneurship Research Conference, Denmark: Aarhus University Institute of Management.

Contreras-Sweet, M. (2015). Immigrant Entrepreneurs Help Fuel Record Growth Streak. Retrieved on May 30, 2015 from https://www.sba.gov/blogs/immigrant-entrepreneurs-help-fuel-recordgrowth-streak.

Cooper, A. C., \& Dunkelberg, W. C. (1986). Entrepreneurship and paths to business ownership. Strategic Management Journal, 7(1), 53-68.

Dana, L. P. (1996). Self-employment in the Canadian Sub-Arctic: An Exploratory Study. Canadian Journal of Administrative Sciences/Revue Canadienne des Sciences de l'Administration, 13(1), 65-77.

Davidsson, P. (2003). The domain of entrepreneurship research: Some suggestions. Advances in Entrepreneurship, Firm Emergence and Growth, 6(3), 315-372.

Davidsson, P., \& Honig, B. (2003). The role of social and human capital among nascent entrepreneurs. Journal of Business Venturing, 18(3), 301-331.

Douglas, D. (2003). Inductive theory generation: A grounded approach to business inquiry. Electronic Journal of Business Research Methods, 2(1), 47-54.

Dyer, J. H., Gregersen, H. B., \& Christensen, C. (2008). Entrepreneur behaviors, opportunity recognition, and the origins of innovative ventures. Strategic Entrepreneurship Journal, 2(4), 317338.

Fairlie, R.W. (2008). Estimating the contribution of immigrant business owners to the U.S. economy. Office of Advocacy Research Summary No. 334. Washington: Small Business Administration.

Foo, M. D. (2011). Emotions and entrepreneurial opportunity evaluation. Entrepreneurship Theory and Practice, 35(2), 375-393.

Foo, M. D., Uy, M. A., \& Baron, R. A. (2009). How do feelings influence effort? An empirical study of entrepreneurs' affect and venture effort. Journal of Applied Psychology, 94(4), 1086-1094.

Friedman, R. A., \& Podolny, J. (1992). Differentiation of boundary spanning roles: Labor negotiations and implications for role conflict. Administrative Science Quarterly, 37, 28-47.

Froschanuer, K. (2001). East Asian and European Entrepreneur Immigrants in British Columbia, Canada: post-migration conduct and pre-migration context. Journal of Ethnic and Migration Studies, 27(2), 225-240.

Furman, J., \& Gray D. (2012). Ten Ways Immigrants Help Build and Strengthen Our Economy, Retrieved on May 30, 2015, from https://www.whitehouse.gov/blog/2012/07/12/ten-waysimmigrants-help-build-and-strengthen-our-economy.

Glaser, B. G. (1992). Emergence vs Forcing: Basics of Grounded Theory Analysis. Sociology Press.

Glaser, B., \& Strauss, A. (1967). The discovery ofgrounded theory. London: Weidenfeld and Nicholson.

Hart, D. M., Acs, Z. J., \& Tracy, S. L. (2009). High-Technology Immigrant Entrepreneurship in the U.S. U.S. Small Business Administration, Office of Advocacy, July 12009.

Hills, G. E. (1995). Opportunity recognition by successful entrepreneurs: A pilot study. Frontiers of Entrepreneurship Research, 15, 105-117. 
Hills, G. E., Shrader, R. C., \& Lumpkin, G. T. (1999). Opportunity recognition as a creative process. Frontiers of entrepreneurship research, 19(19), 216-227.

Hofstede, G., Noorderhaven, N. G., Thurik, A. R., Uhlaner, L. M., Wennekers, A. R. M., \& Wildeman, R. E. (2004). Culture. In Brown, T. E. \& Ulijn, J. (Eds), Innovation, Entrepreneurship and Culture (pp. 162-203). Cheltenham, UK: Edward Elgar.

Hostager, T. J., Neil, T. C., Decker, R. L., \& Lorentz, R. D. (1998). Seeing environmental opportunities: effects of intrapreneurial ability, efficacy, motivation and desirability. Journal of Organizational Change Management, 11(1), 11-25.

Ibrahim, G., \& Galt, V. (2003). Ethnic business development: Toward a theoretical synthesis and policy framework. Journal of Economic Issues, 1107-1119.

Jack, S. L., \& Anderson, A. R. (2002). The effects of embeddedness on the entrepreneurial process. Journal of Business Venturing, 17(5), 467-487.

Kirzner, I. M. (1973). Competition and Entrepreneurship. University of Illinois at UrbanaChampaign's Academy for Entrepreneurial Leadership Historical Research Reference in Entrepreneurship

Kontinen, T., \& Ojala, A. (2011). Network ties in the international opportunity recognition of family SMEs. International Business Review, 20(4), 440-453.

Krueger, N.F. (1993). The impact of prior entrepreneurial exposure on perceptions of new venture feasibility and desirability. Entrepreneurship Theory and Practice, 18(1), 5-21.

Kwon, S. W., \& Arenius, P. (2010). Nations of entrepreneurs: A social capital perspective. Journal of Business Venturing, 25(3), 315-330.

Langford, C.H, Josty, P., \& Holbrook, J.A. (2013). Driving wealth creation \& social development in Canada, 2013 GEM Canada National Report, The Centre for Innovation Studies (THECIS): Calgary, Alberta.

LEAF (2005). The Equality Deficit - Chinese Immigrant Women in Canada. Women's Legal Education and Action Fund (LEAF). LEAF's Person's Day Breakfast, Toronto, November 2.

Light, I., \& Rosenstein, C. (1998). Race, Ethnicity, and Entrepreneurship in Urban America, Aldine Transaction.

Light, I. (2014). America: A Land of the Immigrant Entrepreneur, The Islamic Monthly, Septemebr 1, 2014.

Marger, M.N. (2001). The use of social and human capital among Canadian business immigrants, Journal of Ethnic and Migration Studies, 27(3), 439-453.

Masurel, E., Nijkamp, P., Tastan, M., \& Vindigni, G. (2012). Motivations and Performance Conditions for Ethnic Entrepreneurship. Tinbergen Discussion Paper No. 01-048/3.

Mitchell, J. R., \& Shepherd, D. A. (2010). To thine own self be true: Images of self, images of opportunity, and entrepreneurial action. Journal of Business Venturing, 25(1), 138-154.

Nahapiet, J., \&Ghoshal, S. (1998). Social capital, intellectual capital, and the organizational advantage. Academy of Management Review, 23(2), 242-266.

Ndoen M. L., Gorter, C., Nijkamp, P., \& Reitveld, P. (2000). Entrepreneurial Migration and Regional Opportunities in Developing Countries, Tinbergan Discussion Paper No. 00-086/3.

Nicolaou, N., \& Shane, S. (2009). Can genetic factors influence the likelihood of engaging in entrepreneurial activity?. Journal of Business Venturing, 24(1), 1-22.

Ozgen, E., \& Baron, R. A. (2007). Social sources of information in opportunity recognition: Effects of mentors, industry networks, and professional forums. Journal of Business Venturing, 22(2), 174-192. 
Pécoud, A. (2000). Thinking and rethinking ethnic economies. Diaspora: A Journal of Transnational Studies, 9(3), 439-462.

Portes, A. (2000, March). The two meanings of social capital. In Sociological forum (Vol. 15, No. 1, pp. 1-12). Kluwer Academic Publishers-Plenum Publishers.

Portes, A., \& Sensenbrenner, J. (1993). Embeddedness and immigration: Notes on the social determinants of economic action. American Journal of Sociology, 1320-1350.

Puhakka, V. (2006). Effects of Social Capital on the Opportunity Recognition Process. Journal of Enterprising Culture, 14 (2), 105-124

Putnam, R. (2000). Bowling alone, the collapse and revival of civic America. New York.

Ramos-Rodríguez, A. R., Medina-Garrido, J. A., Lorenzo-Gómez, J. D., \& Ruiz-Navarro, J. (2010). What you know or who you know? The role of intellectual and social capital in opportunity recognition. International Small Business Journal, 28(6), 566-582.

Razin, E., \& Scheinberg, D. (2001). Immigrant entrepreneurs from the former USSR in Israel: Not the traditional enclave economy. Journal of Ethnic and Migration Studies, 27(2), 259-276.

Riquelme, H.E. (2013). In Search of Entrepreneurial Opportunities - An Integrated Model. Journal of Enterprising Culture, 21 (3), 249-274.

Sanders, J., Nee, V., \& Sernau, S. (2002). Asian immigrants' reliance on social ties in a multiethnic labor market. Social Forces, 81(1), 281-314.

Saxenian, A. (2002). Brain circulation. How high-skill immigration makes everyone better off. Brookings Review, 20(1), 28-31.

SBA Report. (2012). https://www.sba.gov/sites/default/files/advocacy/Small_Business_Economy _2012.pdf

Schiller, N. G., Basch, L., \& Blanc-Szanton, C. (1992). Towards a transnational perspective on migration: race class ethnicity and nationalism reconsidered.

Sequeira, J. M., \& Rasheed, A. A. (2006). Start-up and growth of immigrant small businesses: the impact of social and human capital. Journal of Developmental Entrepreneurship, 11(04), 357375.

Shane, S. (2000). Prior knowledge and the discovery of entrepreneurial opportunities. Organization Science, 11(4), 448-469.

Shane, S., \& Venkataraman, S. (2000). The promise of entrepreneurship as a field of research. Academy of Management Review, 25(1), 217-226.

Shepherd, D. A., \& DeTienne, D. R. (2005). Prior knowledge, potential financial reward, and opportunity identification. Entrepreneurship Theory and Practice, 29(1), 91-112.

Simon, M., Houghton, S. M., \& Aquino, K. (2000). Cognitive biases, risk perception, and venture formation: How individuals decide to start companies. Journal of Business Venturing, 15(2), 113-134.

Singh, R. P., Hills, G. E., Lumpkin, G. T., \& Hybels, R. C. (1999, August). The entrepreneurial opportunity recognition process: Examining the role of self-perceived alertness and social networks. In Academy of Management Proceedings (Vol. 1999, No. 1, pp. G1-G6). Academy of Management.

Singh, R. P. (2001). A comment on developing the field of entrepreneurship through the study of opportunity recognition and exploitation. Academy of Management Review, 26(1), 10-12.

Smith, А. (1937). An Inquiry into the Nature and Causes of the Wealth of Nations. РиполКлассик.

Stark, O., \& Wang, Y. (2002). Inducing human capital formation: migration as a substitute for subsidies. Journal of Public Economics, 86(1), 29-46. 
Swidler, A. (2001). Talk of Love. How Culture Matters. Chicago: University of Chicago Press.

Tang, J., Kacmar, K. M. M., \& Busenitz, L. (2012). Entrepreneurial alertness in the pursuit of new opportunities. Journal of Business Venturing, 27(1), 77-94.

Tumasjan, A., \& Braun, R. (2012). In the eye of the beholder: How regulatory focus and self-efficacy interact in influencing opportunity recognition. Journal of Business Venturing, 27(6), 622-636.

Vaghely, I. P., \& Julien, P. A. (2010). Are opportunities recognized or constructed?: An information perspective on entrepreneurial opportunity identification. Journal of Business Venturing, 25(1), 73-86.

Vinogradov, E., \& Kolvereid, L. (2007). Cultural background, home country national intelligence and self-employment rates among immigrants in Norway. Paper presented the 8 th ISIR Conference, Amsterdam, Sweden, 13-15 December, 2007.

Waldinger, R., Aldrich, H., \& Ward, R. (1990). Opportunities, group characteristics, and strategies. Ethnic Entrepreneurs, 13-48.

Zhou, M. (2004). Revisiting ethnic entrepreneurship: convergencies, controversies, and conceptual Advancements1. International Migration Review, 38(3), 1040-1074. 


\section{Authors}

The contribution share of authors is equal and amounted to $50 \%$ each of them.

\section{Malavika Sundararajan}

Assistant Professor in the Anisfield School of Business, Ramapo College of New Jersey, Mahwah, New Jersey, USA. She teaches Ethics in Business, Organizational Behavior and Entrepreneurship. Her research focusing on applying cognitive and behavioral models in the area of Entrepreneurial Opportunity recognition and ethical decision making. She has a Ph.D. in Management from Rensselaer Polytechnic Institute (New York, USA).

\section{Binod Sundararajan}

Associate Professor of Management in the Rowe School of Business at Dalhousie University in Halifax, Nova Scotia, Canada. He teaches Business Communication. His research focuses on Social network analysis, Historical data analysis, Systems theory, Constructivism, Thematic analysis, Language, Organizational learning, Networking technologies. He has a Ph.D. in Communications \& Rhetoric from Rensselaer Polytechnic Institute (New York, USA).

\section{Correspondence to:}

Dr. Malavika Sundararajan ASB 014, Anisfield School of Business,

Ramapo College of New Jersey

505 Ramapo Valley Road

Mahwah, New Jersey, USA

Email:msundara@ramapo.edu

\section{Acknowledgementsand Financial Disclosure}

The authors would like to thank the anonymous referees for their useful comments, which allowed us to increase the value of this article. The authors would also like to express their gratitude to the editor for his valuable comments, which led to a highly refined version of the idea and model, increasing its value to the field.

\section{Copyright and License}

(c) $(1) \Theta$

This article is published under the terms of the Creative Commons Attribution - NonCommercial - NoDerivs (CC BY-NC-ND 3.0) License http://creativecommons.org/licenses/by-nc-nd/3.0/ 